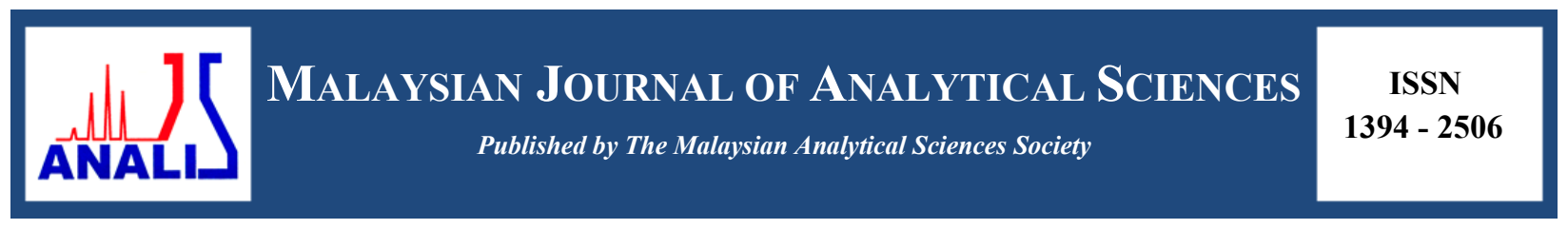

\title{
CHARACTERIZATION STUDIES OF SODIUM ALGINATE/SULFONATED GRAPHENE OXIDE BASED POLYMER ELECTROLYTE MEMBRANE FOR DIRECT METHANOL FUEL CELL
}

\author{
(Kajian Pencirian Bagi Membran Elektrolit Polimer Berasaskan Sodium Alginat/Sulfonat Grafin \\ Oksida untuk Sel Bahan Api Metanol Langsung)
}

\author{
Norazuwana Shaari $^{1 *}$ and Siti Kartom Kamarudin ${ }^{2}$ \\ ${ }^{I}$ Fuel Cell Institute \\ ${ }^{2}$ Department of Chemical and Process Engineering, Faculty of Engineering and Built Environment \\ Universiti Kebangsaan Malaysia, 43600 UKM Bangi, Selangor, Malaysia \\ *Corresponding author: ctie@ukm.edu.my
}

Received: 21 October 2015; Accepted: 14 June 2016

\begin{abstract}
This work used blending and casting method to synthesis sodium alginate/sulfonated-GO (SA/SGO) polymer electrolyte membrane for direct methanol fuel cell (DMFC). The composition of sulfonated-GO in the membrane is varied from $0 \mathrm{wt} \%$ to 1 $w t \%$. The functional groups in the membrane were confirmed by Fourier Transform Infrared analysis. The water uptake capacity of the membrane as observed was reduced with addition of sulfonated-GO as filler in the membrane. Thus, the proposed membrane has good potential to be an alternative membrane in DMFC application.
\end{abstract}

Keywords: fuel cell, graphene oxide, alginate, direct methanol fuel cell

\begin{abstract}
Abstrak
Kerja ini menggunakan kaedah pemutus dan pengadunan untuk sintesis polimer membran elektrolit sodium alginat/ sulfonat-GO (SA/SGO) untuk aplikasi sel bahan api metanol langsung (DMFC). Komposisi sulfonat-GO dalam membran diubah daripada $0 \%$ berat kepada $1 \%$ berat. Kumpulan berfungsi dalam membran telah disahkan oleh analisis Infra merah transformasi Fourier. Kapasiti pengambilan air oleh membran seperti yang diperhatikan telah berkurangan dengan penambahan sulfonat-GO sebagai pengisi dalam membran. Oleh itu, membran yang dicadangkan mempunyai potensi yang baik untuk menjadi membran alternatif dalam aplikasi DMFC.
\end{abstract}

Kata kunci: sel bahan api, grafin oksida, alginat, sel bahan api metanol langsung

\section{Introduction}

The advantages of DMFC as green technology exclusively in portable application tools such as laptop, camera and etc., has been attracted many researchers to explore their enhancement. With very less pollutant emission at the end process, low temperature works condition, compact design, and high power density is the enforcement of their commercialization today [1]. However, there are several things that hindered this commercialization process. The DMFC issues is relate to the low power density, sluggish in kinetic reaction of methanol oxidation, methanol crossover phenomena that leads to the mixed potential and fuel wasting in cathode side and also the very expensive of Nafion membrane that was used as main polymer electrolyte membrane in almost Fuel Cell types systems including DMFC [2]. 
Nafion is not well known as polymer electrolyte membrane due to its specialty in high proton conductivity, high mechanical strength, and strong chemical stability and well perform in fuel cell performance. It can be said that until now Nafion is the most ideal polymer electrolyte membrane candidate. But, the awareness of fuel cell researchers was increasing nowadays on the bad side of Nafion membrane especially their harmful material used in Nafion, fluorine, and high methanol crossover as well [3]. Thus, many efforts on finding new material for suited as polymer electrolyte membrane function to replace Nafion membrane. The environmental friendly, low cost, and low methanol crossover material seems the most needed characteristics to improved Nafion drawbacks. Alginate is the biopolymer who have that characteristics as it was selected in many applications such medical, packaging, also fuel cell as main polymer matrix membrane [4].

Alginate is a prominent water-soluble polysaccharide found in brown seaweed consisting of (1-4)-linked $\beta$-Dmannuronic acid (M) and $\alpha$-L-gluronic acid (G) units. It has very high water absorption as can absorb 200-300 times its own weight in water. Alginate is able to be invented into a variety forms such as film, microspheres and fibers because of their reversible solubility [5]. However, the application of alginate is limited owing to several weaknesses that high water solubility and low mechanical strength [6]. Its hydrophilicity can be the major problem in DMFC performance because over water uptake in polymer electrolyte membrane will leads to the high swelling ratio thus burst the membrane during working process. Other than that sodium alginate membrane easy to dissolve in wet condition thus lowered its mechanical stability[7].

Inorganic filler such as CNT, zeolite, silica and graphene oxide is the common used to reduce hydrophilic characteristics of polymer. Nowadays, the graphene based material seems conquer the various function including as a filler in membrane [8]. Sulfonated Graphene Oxide is the product of graphene oxide modification process which has many attractive properties. The capability of SGO to be inorganic filler was recognized due to the presence of sulfonic acid group $\left(\mathrm{SO}_{3} \mathrm{H}^{-}\right)$on graphene oxide sheets which can contribute in good hydrogen bonding formation with other polymers. The formation of strong hydrogen bonding between SGO and Sodium Alginate polymer matrix can decreased the hydrophilicity and water uptake capacity due to the 'blocking effect' function of SGO [9]. Based on our research, there is no bio-composite Sodium Alginate/sulfonated-GO has been produced yet for DMFC application. Therefore, this research will combine the advantages of Sodium Alginate and sulfonated-GO to form a bio-membrane that have high durability which reduced their water uptake capacity to avoid swelling problem. Effect of sulfonated-GO addition and their interaction were studied using physical observation, Fourier Transform Infrared (FTIR) analysis and water uptake performance test.

\section{Materials}

\section{Materials and Methods}

TIMREX PG25 graphene oxide was purchased from TIMCAL Ltd. Methanol $\left(\mathrm{CH}_{3} \mathrm{OH}, 99.7 \%\right)$. Sodium alginate, hydrogen peroxide aqueous solution $\left(\mathrm{H}_{2} \mathrm{O}_{2}, 35 \%\right)$, sulfanilic acid, and sodium nitrite solution were obtained from Sigma Aldrich. These chemicals were used as received without further purification. Deionized (DI) water through a Millipore system (Milli-Q) was used in all experiments.

\section{Preparation of sulfonated graphene oxide}

Graphene oxide by $50 \mathrm{mg}$ added to $8 \mathrm{ml}$ of $0.06 \mathrm{M}$ sulfanilic acid solution at a temperature of $70{ }^{\circ} \mathrm{C}$. With continuous stirring, $2 \mathrm{ml}$ of sodium nitrite solution is added dropwise to the mixture and let stand for 12 hours at a constant temperature of $70^{\circ} \mathrm{C}$. After reaction occurs, the mixture was washed and collected by centrifuge. Then, collected sulfonated-GO is washed for several times more with water until reaching $\mathrm{pH}$ 7. The washed SGO solution was dried and SGO powder was obtained.

\section{Preparation of sulfonated-GO based sodium alginate bio-composite films}

Sodium alginate was dissolved in deionized water $1 \%(\mathrm{w} / \mathrm{v})$ to obtain a solution of alginate. The various weight percentage of sulfonated-GO $(0.2 \mathrm{wt} \%-1.0 \mathrm{wt} \%)$ was added into Sodium alginate solution to produce a SA/SGO composite film. The mixture must be stirred continuously for 30 minutes with a magnetic stirrer. Heterogeneous solution was transferred to a glass substrate, left at room temperature for 72 hours for thin film formation process. A 
series of bio-composite film were coded as SA, SA/SGO-1, SA/SGO-2, SA/SGO-3, SA/SGO-4, SA/SGO-5 according to the different $\mathrm{wt} \%$ of sulfonated-GO loading.

\section{Characterization}

The functional groups of Al/SGO with were confirmed by Fourier transform infrared spectroscopy (FTIR). Thirtytwo scans were accumulated for FTIR characterization with a resolution of $4 \mathrm{~cm}^{-1}$ for each spectrum.

\section{Performance test (water uptake)}

Changes in weight and length (or thickness) of wet and dry membranes will be able to determine the rate of water absorption and swelling ratio of the membrane. The membrane was soaked in water for 24 hours at room temperature. In the wet condition, the weight of membrane was recorded which the liquid droplets on the membrane surface was removed. Earlier moist membrane was dried under vacuum pressure at temperature $100{ }^{\circ} \mathrm{C}$ for 1 hour. Weight of the membrane in the dry state was also recorded. Using equations (1), water uptake (WU\%) can be determined.

$$
\mathrm{WU} \%=\frac{\text { mass }_{\text {wet }}-\text { mass }_{\mathrm{dry}}}{\text { mass }_{\mathrm{dry}}} \times 100
$$

\section{Physical observation}

\section{Results and Discussion}

Polymer electrolyte based Sodium alginate thin film with different weight percentage of sulfonated-GO was observed physically and the Figure of each membrane thin film is presented in Figure 1. The colours of membranes become dark when concentration of sulfonated-GO was increased. However, the films were still flexible and homogeneous.

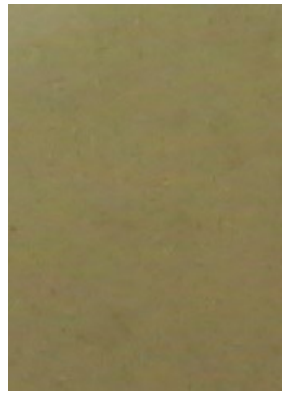

$0.6 \mathrm{wt} \% \mathrm{SGO}$

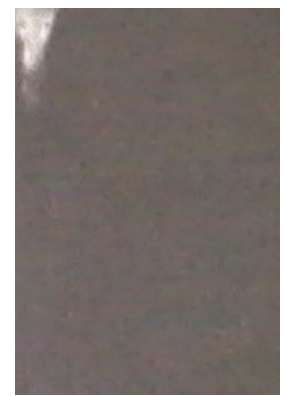

$0.8 \mathrm{wt} \% \mathrm{SGO}$

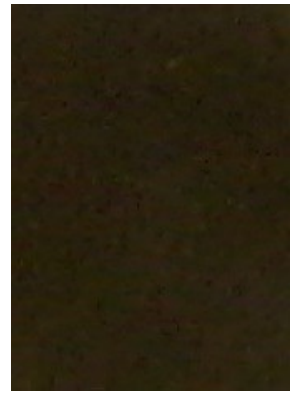

$1.0 \mathrm{wt} \% \mathrm{SGO}$

Figure 1. Physical observation sodium alginate membrane with different wt. \% of sulfonated-GO

\section{Fourier transform infrared spectroscopy}

The interactions between sodium alginate and sulfonated-GO were investigated by FTIR analysis. The FTIR spectrum for sodium alginate and SA/SGO membrane were presented in transmittance bands as shown in Figure 2. The FTIR spectrum of SA was compared with previous work and it seems similar. There are four major spectrum belongs to SA which at $3347 \mathrm{~cm}^{-1}, 1600 \mathrm{~cm}^{-1}, 1414 \mathrm{~cm}^{-1}$ and $1030 \mathrm{~cm}^{-1}$ and its attributed to $\mathrm{OH}$ stretching vibration, $\mathrm{COO}^{-}$stretching vibration of carboxylate salt group, and stretching vibration of C-O-C groups, respectively [10]. The dominant spectrum of GO was emerged at $3401 \mathrm{~cm}^{-1}$ for $\mathrm{OH}$ group stretching vibration, $1624 \mathrm{~cm}^{-1}$ for $\mathrm{C}=\mathrm{C}$ stretching vibration and $1043 \mathrm{~cm}^{-1}$ assigned to $\mathrm{C}-\mathrm{O}$ groups vibration. All the spectrum of Sodium Alginate and Graphene Oxide was seen exist in the SA/SGO membrane composite. In addition, the membrane composite also has new spectra instead of SA and GO dominant spectrum which appear at around $1024 \mathrm{~cm}^{-1}, 1080 \mathrm{~cm}^{-1}$ and $1280 \mathrm{~cm}^{-1}$ 
which attributed to the $\mathrm{S}-\mathrm{O}$ symmetrical, asymmetric stretching vibration $(\mathrm{O}=\mathrm{S}=\mathrm{O})$, and sulfonic acid groups bands $\left(-\mathrm{SO}_{3} \mathrm{H}\right)$, respectively.

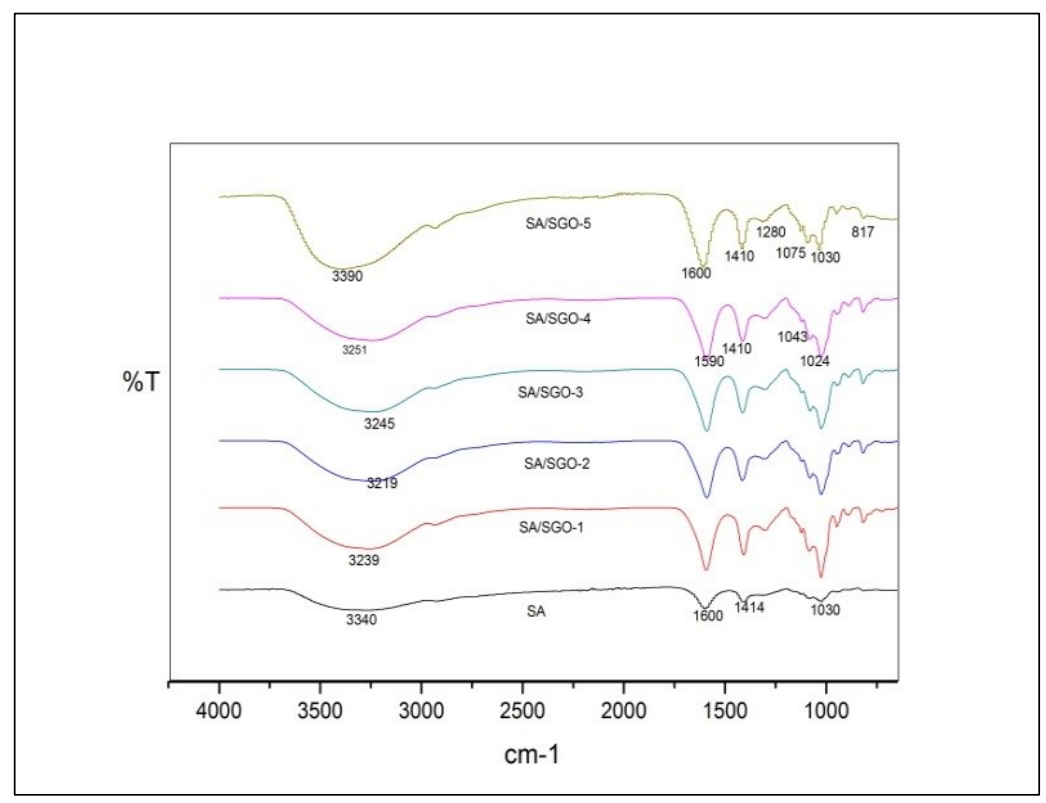

Figure 2. FTIR spectra of Sodium Alginate and various wt. \% of sulfonated-GO in sodium alginate membrane

The broadening happened for $\mathrm{OH}$ group spectrum at $3347 \mathrm{~cm}^{-1}$ it was shifted to the smaller wavelength of $3239 \mathrm{~cm}^{-}$ ${ }^{1}$ which is signal that existing of hydrogen bonding interaction between SA and sulfonated-GO [11]. Other than that, the spectrum of SA at $1414 \mathrm{~cm}^{-1}$ was also somewhat shifted to the $1410 \mathrm{~cm}^{-1}$ wavelength. This spectrum shifting occurred regarding to the existence of hydrogen bonding formation attributed to the interaction of hydroxyl groups in Alginate and polar groups in Sulfonated-GO [9]. This interaction is important factor for increase the mechanical stability of Sodium Alginate which can form and interactive 'blocking effect' especially for water solubility reduction.

\section{Performance test (water uptake)}

As mentioned above, the performance of polymer electrolyte membrane will be degrading if the amount of water absorbed is over the optimum range. The overloading of water leading to the swelling problem thus membrane will be ruptured. However, the water presence is still important for hydronium ion sources in proton transfer. Thus, the water uptake test is important to ensure that the polymer electrolyte membrane absorbed water in ideal range. Figure 3 are present the result of water uptake of SA-SGO membrane with variation of sulfonated-GO wt $\%$. As presented, the pristine sodium alginate membrane has very high water uptake capacity $(180 \%)$, which is contra to SA-SGO membrane that have lower water uptake capacity with different content of sulfonated-GO in the membrane. The increasing amount of sulfonated-GO has reduced water uptake due to the blocking ability as filler in the membrane [11]. Higher sulfonated-GO content brings to higher barrier for water absorption of the membrane. The hydrogen bonding existed between sulfonated-GO filler and sodium alginate polymer has strengthened the interfacial adhesion of the membrane composite thus reduce the water uptake capacity. The stronger interfacial adhesion, the lesser the gap size between filler and polymer which the gap is the space for water molecules pass through the membrane [9]. 


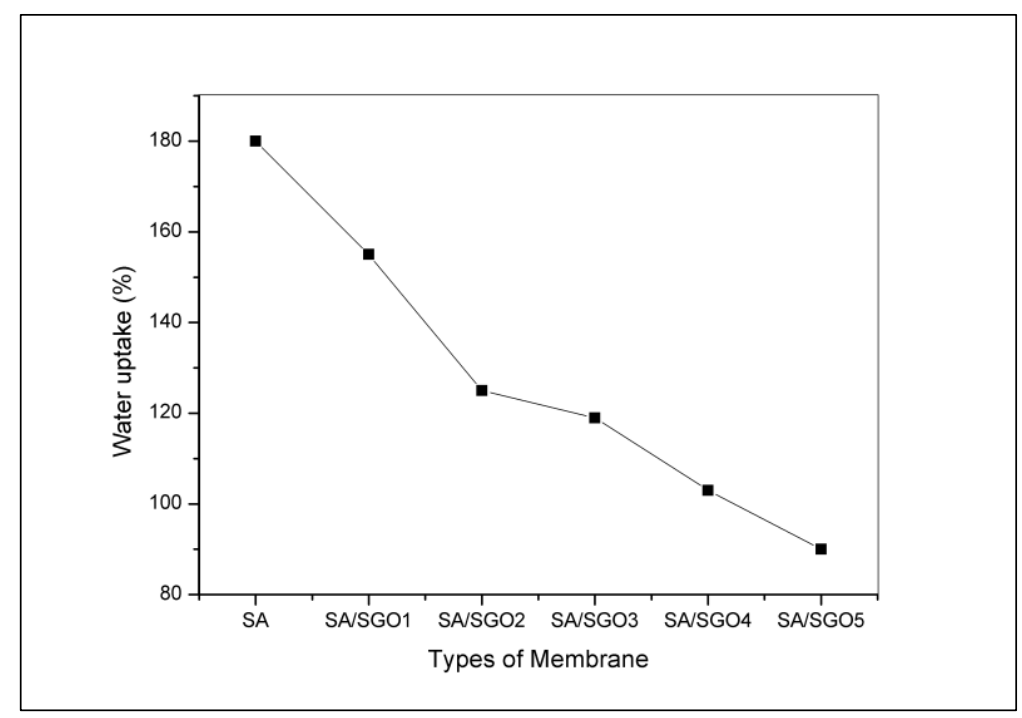

Figure 3. Water uptake of Sodium Alginate and SA/SGO membrane

\section{Conclusion}

The FTIR analysis has confirmed that there is interaction between sodium alginate biopolymer and sulfonated-GO due to the presence of primary spectrum of sodium alginate and GO in the bio-composite. The hydrogen bonding interaction between SA and sulfonated-GO possibly increase the interfacial adhesion between SA and sulfonatedGO consequently enhance the mechanical stability of the bio-composite. The results showed that the existence of sulfonated-GO as filler in sodium alginate biopolymer has reduced the water solubility of the polymer. The lowest water uptake for bio-composite membrane is $90 \%$ (SA/SGO-5) with half reduction compared to pure sodium alginate. The present SA/SGO membrane suggested to be further explored in terms of morphology, structure and other performance such proton conductivity and methanol permeability. The excellent water uptake test is the good indicator that this membrane can perform well in DMFC application. The combination between Sodium Alginate polymer and sulfonated-GO seems match to each other with good interaction occur. The major drawback of Nafion also can be solved by using cheaper Sodium Alginate polymer. Thus, the findings in this study can be part of enforcement of DMFC application commercialization in future.

\section{Acknowledgements}

The authors gratefully acknowledge the financial support given for this work by the Universiti Kebangsaan Malaysia (UKM) under GUP-2013-031 and Ministry of Education FRGS/2/2013/TK06/UKM/01/1.

\section{References}

1. Kamaruddin, M. Z. F., Kamarudin, S. K., Daud, W. R. W. and Masdar, M. S. (2013). An overview of fuel management in direct methanol fuel cells. Renewable and Sustainable Energy Reviews, 24: 557 -565.

2. Ahmad, H., Kamarudin, S.K., Hasran, U.A., Daud W.R.W. (2010). A Novel Hybrid Nafion-Pbi-Zp Membrane For Direct Methanol Fuel. International Journal of Hydrogen Energy, 36: 14668-14677.

3. Shaari, N. and Kamarudin, S. K. (2015). Chitosan and alginate types of bio-membrane in fuel cell application: An overview. Journal of Power Sources, 289: 71 - 80.

4. Pasini Cabello, S. D., Mollá, S., Ochoa, N. A., Marchese, J., Giménez, E. and Compañ, V. (2014). New biopolymeric membranes composed of alginate-carrageenan to be applied as polymer electrolyte membranes for DMFC. Journal of Power Sources, 265: 345 - 355.

5. Jost, V., Kobsik, K., Schmid, M. and Noller, K. (2014). Influence of plasticiser on the barrier, mechanical and grease resistance properties of alginate cast films. Carbohydrate Polymers, 110: 309 -319.

6. Li, J., He, J., Huang, Y., Li, D. and Chen, X. (2015). Improving surface and mechanical properties of alginate films by using ethanol as a co-solvent during external gelation. Carbohydrate Polymers, 123: 208 - 216. 
7. Tavassoli-Kafrani, E., Shekarchizadeh, H. and Masoudpour-Behabadi, M. (2016). Development of edible films and coatings from alginates and carrageenans. Carbohydrate Polymers, 137: 360 - 374.

8. Yuan, T., Pu, L., Huang, Q., Zhang, H., Li, X. and Yang, H. (2014). An effective methanol-blocking membrane modified with graphene oxide nanosheets for passive direct methanol fuel cells. Electrochimica Acta, 117: 393 - 397.

9. Jiang, Z., Zhao, X. and Manthiram, A. (2013). Sulfonated poly(ether ether ketone) membranes with sulfonated graphene oxide fillers for direct methanol fuel cells. International Journal of Hydrogen Energy, 38(14): 5875 5884 .

10. Ionita, M., Pandele, M. A. and Iovu, H. (2013). Sodium alginate/graphene oxide composite films with enhanced thermal and mechanical properties. Carbohydrate Polymers, 94(1): 339 - 344.

11. Heo, Y., Im, H. \& Kim, J. (2013). The effect of sulfonated graphene oxide on sulfonated poly (ether ether ketone) membrane for direct methanol fuel cells. Journal of Membrane Science, 425 - 426: 11 -22. 